\title{
Evaluation of the Perception and Management of the Terminal Process by Nurses in Terminal Patients
}

\author{
Guler Eraslan Doganay ${ }^{1(\mathrm{ID})}$, Mustafa Ozgur Cirik ${ }^{1(\mathrm{ID})}$ \\ ${ }^{1}$ Department of Anesthesiology and Reanimation, Ministry of Health University Atatürk Chest Diseases and Thoracic Surgery \\ Training and Research Hospital, Ankara, Turkey
}

Copyright@ Author(s) - Available online at https://dergipark.org.tr/en/pub/mbsjohs Content of this journal is licensed under a Creative Commons Attribution-NonCommercial 4.0 International License,

Received: 15 July 20201 Accepted:13 December 2021, Published online: 31 December 2021

(C) Ordu University Institute of Health Sciences, Turkey, 2021

\begin{abstract}
Objective: It is important that nurses can perceive and control their feelings about the disease, life, death and loss in order to perform the 'good death' process in terminal patients and to provide better care to patients. In this study, we aimed to evaluate the perception of the terminal process by the nurses and how they manage this process.

Methods: The study was conducted at Ataturk Chest Diseases and Thoracic Surgery Training and Research Hospital with the ethical approval numbered 05.03.2020/665. Nurses who currently work or who have worked before in intensive care or palliative service were asked to answer the questionnaire "Perception and Management of the Terminal Process by Nurses". The answers were evaluated and interpreted statistically. Results: The total number of volunteer nurses participating in the study was 55 . The mean age of the nurses was $30.05 \pm 6.4$, of which $21.8 \%$ were male and $78.2 \%$ were female. $30.9 \%$ had more than 10 years of professional experience.

The participants $(89.1 \%)$ thought that care for the terminal stage patient was a right and comfort-peace, but they were reluctant to provide care due to sadness. They are reluctant to communicate with patients and their relatives in the terminal process and they often directed the patient and their relatives to talk to the doctor.

Conclusion: Nurses are reluctant to care and avoid communicating with the patient and their families. Therefore, terminal process, patient communication and emotion management awareness should be increased with in-service training. The terminal process should be ensured to be better manageable for auxiliary medical personnel. Patients waiting to die should be ensured to have the good death they deserve.
\end{abstract}

Key words: Terminal Stage, Death, Palliative, Nurse

Suggested Citation: Eraslan Doganay G, Cirik M. C. Evaluation of the Perception and Management of the Terminal Process by Nurses in Terminal Patients. Mid Blac Sea Journal of Health Sci, 2021; 7(3):354-359

\section{Address for correspondence/reprints:}

Guler Eraslan Doganay

Telephone number: $+90(533) 2182747$

E-mail: gulerdoganay@hotmail.com.tr

\section{Introduction}

The terminal period is when death occurs within weeks, due to diseases or advancing age. Patients or their relatives, who cannot manage this period at home due to pain or difficulty in care, prefer hospitals. Therefore, many terminal stage patients spend this period in the intensive care or palliative service. In order for nurses to provide better care to these patients, they should know what the physical and psychological needs of the patients are and accept the death event. In order to fully assist a dying patient and his family, the nurse must first recognize her own feelings $(1,2)$. 
Natural death is accepted as a "good death", where the privacy of the person is respected, pain and other symptoms can be kept under control, emotional, spiritual, and religious needs are met, and there is time to say goodbye to loved ones. In the terminal period, patients' expectations are to eliminate their current complaints, especially pain, improve their quality of life, and spend their remaining time with their loved ones. A terminally ill patient experiences mixed emotions after learning that he or she will die. The psychological care of the dying patient is as important as the physical care (3). In patients with fear of death, the level of anxiety increases, changes in attitudes and behaviors may develop and it becomes difficult to adapt to the environment (4).

In the terminal period, nursing care and management consist of managing the patient's anxiety, fear of death, depressive mood, trying to reduce the patient's symptoms such as pain by complying with the treatment, increasing the quality of life and strengthening the patient's hope as much as possible (5). Studies show that nurses are afraid of death and facing the terminally ill patients and they prefer to work in wards where there are no terminally ill patients $(1,2)$. Nurses are the health professionals who spend the most time with the patient for the realization of the 'good death' process in terminal patients. Nurses' ability to perceive and control their own feelings about illness, life, death and loss will be effective in providing better care to patients.

The aim of this study is to evaluate how the terminal process is perceived by nurses, how they manage this process, and to determine the perceptions and concerns of nurses in the terminal process.

\section{Methods}

The study was performed at Atatürk Chest Diseases and Thoracic Surgery Training and Research Hospital, with the ethical approval numbered 05.03.2020/665.

The study is a face-to-face volunteer-based survey study and all nurses who worked or currently working in the intensive care and palliative service were invited for the survey, only two of them did not participate in the survey because they did not volunteer and were excluded from the study. A total of 55 nurses participated in the survey. Nurses participating in the survey were asked face-to-face to choose one of the multiple choice answers for 19 questions in the "Questionnaire of Nurses' Perception and Management of the Terminal Process in Terminal Patients". The answers were interpreted statistically.

The criteria for participation in the questionnaire were volunteering and having previously worked or currently working in the intensive care or palliative service.

The exclusion criteria are, those who work in the intensive care or palliative service and did not volunteer to participate in the survey.

\section{Statistical analysis}

Statistical analyzes were evaluated with the SPSS 22.0 (Statistical Program Social Sciences) package program.

In the evaluation of data, frequencies and percentages were given for qualitative data. Kolmogrow Smirrov test was used to determine the normal distribution of quantitative data. For quantitative data, mean and standard deviation values were given from descriptive statistical methods, and for qualitative data, their frequency and percentage (\%) were given.

\section{Results}

The total number of volunteer nurses participating in the study was 55. Only two nurses were excluded because they did not volunteer to participate in the survey.

The mean age of the interviewers was 27.7, and $21.8 \%$ were male and $78.2 \%$ were female. $23.6 \%$ of them are in the first year of their professional life. $45.5 \%$ have $2-10$ years of experience and $30.9 \%$ have more than 10 years of professional experience. The units in which the interviewers worked at the time they answered the questionnaire; $14.5 \%$ were in the service, $16.4 \%$ were in palliative care and $69.1 \%$ were in intensive care. According to the working years of the interviewers in the unit where they worked, 3 people had been working in the same unit for 7 years and 49 participants for $1-2$ years . $54.5 \%$ of the nurses participating in the survey were married and $47.3 \%$ had children (Table 1). 
Table 1. Distribution of Demographic Characteristics of Participants

\begin{tabular}{|c|c|c|c|}
\hline \multirow{2}{*}{$\begin{array}{l}\text { Age, }{ }^{\bar{X}} \pm \text { SS } \\
\text { (Min-Max) }\end{array}$} & & \multirow{2}{*}{\multicolumn{2}{|c|}{$\begin{array}{lc}\mathbf{n} & (\boldsymbol{\%}) \\
30.05 \pm 6.40(21-45)\end{array}$}} \\
\hline & & & \\
\hline \multirow{2}{*}{ Gender } & Female & 43 & $(78.2)$ \\
\hline & Male & 12 & $(21.8)$ \\
\hline \multirow{3}{*}{$\begin{array}{l}\text { Education } \\
\text { Status }\end{array}$} & High School & 9 & $(16.4)$ \\
\hline & College & 18 & $(32.7)$ \\
\hline & University & 28 & $(50.9)$ \\
\hline \multirow{3}{*}{$\begin{array}{l}\text { Working } \\
\text { year in the } \\
\text { profession }\end{array}$} & $0-1$ year & 13 & $(23.6)$ \\
\hline & $2-10$ years & 25 & $(45.5)$ \\
\hline & More than 10 years & 17 & $(30.9)$ \\
\hline \multirow{3}{*}{ Department } & Service & 8 & $(14.5)$ \\
\hline & Palliative care & 9 & $(16.4)$ \\
\hline & Intensive care & 38 & $(69.1)$ \\
\hline \multirow{4}{*}{$\begin{array}{l}\text { Working } \\
\text { year in } \\
\text { current } \\
\text { department }\end{array}$} & 1 year & 20 & $(36.4)$ \\
\hline & 2 years & 29 & $(52.7)$ \\
\hline & 3 years & 3 & $(5.5)$ \\
\hline & 7 years & 3 & $(5.5)$ \\
\hline \multirow{2}{*}{$\begin{array}{l}\text { Marital } \\
\text { Status }\end{array}$} & Married & 30 & $(54.5)$ \\
\hline & Single & 25 & $(45.5)$ \\
\hline \multirow{2}{*}{$\begin{array}{l}\text { Status of } \\
\text { having } \\
\text { children }\end{array}$} & Yes & 26 & $(47.3)$ \\
\hline & No & 29 & $(52.7)$ \\
\hline
\end{tabular}

$81.5 \%$ of the nurses were involved in the death process of any of their relatives. $40.6 \%$ of them had experienced the death process of their first degree relative (spouse, mother-father-child-sibling), 34.5\% of them had experienced the death process of a family's elder such as grandparents. $85.4 \%$ of them stated that they were very sorry for the loss they experienced (Table 2).

The $52.7 \%$ of nurses received terminal patient care training. The answers given by the nurses to the questions about terminal patient perception and management were evaluated and the following results have emerged (Table 3 ).

To the question "How do you treat a patient who's worried about death?", $58.2 \%$ do not want to take responsibility by directing the patient to a doctor or psychologist. $27.3 \%$ of them believe that they can manage the process of death.

$58.1 \%$ of the nurses think that the patient in the terminal process should not be forced for treatment and nutrition, and even that the treatment is torture for the patient. $52.7 \%$ of nurses said they were reluctant to treat terminally ill patients because they were worried that the treatment was causing pain to the patient, and $21.6 \%$ of them thought that the treatment increased the hope of the relatives of the patients.
Table 2. Distribution of Participants' Thoughts About Death and Their Situations of Encountering Death

\begin{tabular}{|c|c|c|c|}
\hline & & $\bar{n}$ & $(\%)$ \\
\hline \multirow{3}{*}{$\begin{array}{l}\text { 11. What do you } \\
\text { think about death? }\end{array}$} & $\begin{array}{l}\text { The last process of a } \\
\text { person's life, } \\
\text { extinction }\end{array}$ & 24 & $(43.6)$ \\
\hline & $\begin{array}{l}\text { The beginning of } \\
\text { another life }\end{array}$ & 30 & $(54.5)$ \\
\hline & $\begin{array}{l}\text { We don't have enough } \\
\text { information about } \\
\text { death yet. }\end{array}$ & 1 & $(1.8)$ \\
\hline \multirow{2}{*}{$\begin{array}{l}\text { 12. Have you ever } \\
\text { lost a loved one or } \\
\text { someone close to } \\
\text { you? }\end{array}$} & Yes & 44 & $(81.5)$ \\
\hline & No & 11 & $(18.5)$ \\
\hline \multirow{5}{*}{$\begin{array}{l}\text { 12a. If you lost. } \\
\text { what was the degree } \\
\text { of closeness of your } \\
\text { lost relative with } \\
\text { you? }\end{array}$} & $\begin{array}{l}\text { First-degree relatives } \\
\text { such as parents, } \\
\text { children, siblings } \\
\end{array}$ & 16 & $(29.7)$ \\
\hline & Spouse & 6 & $(10.9)$ \\
\hline & $\begin{array}{l}\text { Family elders like } \\
\text { grandparents }\end{array}$ & 19 & $(34.5)$ \\
\hline & $\begin{array}{l}\text { Second degree } \\
\text { relatives such as uncle } \\
\text { and aunt }\end{array}$ & 9 & $(16.4)$ \\
\hline & Friend & 1 & $(1.8)$ \\
\hline \multirow{3}{*}{$\begin{array}{l}\text { 12b. How did you } \\
\text { handle the loss? }\end{array}$} & $\begin{array}{l}\text { I thought of my own } \\
\text { death, I got scared. }\end{array}$ & 3 & (6.3) \\
\hline & $\begin{array}{l}\text { I was very sad and } \\
\text { cried because I } \\
\text { couldn't see him/her. }\end{array}$ & 41 & $(85.4)$ \\
\hline & $\begin{array}{l}\text { I was worried for her, } \\
\text { I felt anxiety that I } \\
\text { couldn't help her } \\
\text { anymore. }\end{array}$ & 4 & (8.3) \\
\hline
\end{tabular}

For the care of the patient in the terminal process, the vast majority of nurses $(89.1 \%)$ believe that care for the patient is a right and comfort-peace. However, the majority $(85.4 \%)$ stated that they were aware that their efforts would not change the result and that they were reluctant to give care due to sadness and weariness.

Only $5.5 \%$ are emotionally affected by the loss of their patient in the terminal process. $94.5 \%$ evaluate the process as normal and think that it is a positive outcome for the patient.

The $43.4 \%$ of participants are reluctant to communicate with patients and their relatives in the terminal process. $55.6 \%$ stated that they directed patients and their relatives to talk to the doctor. 
Table 3. Distribution of Participants' Approach to The Terminal Patient

\begin{tabular}{|c|c|c|c|}
\hline & & $\bar{n}$ & $(\%)$ \\
\hline \multirow[b]{2}{*}{$\begin{array}{l}\text { 9. Have you ever } \\
\text { had a relative who } \\
\text { couldn't meet the } \\
\text { personal needs you } \\
\text { had to look after? }\end{array}$} & Yes & 13 & $(23.6)$ \\
\hline & No & 42 & $(76.4)$ \\
\hline \multirow{2}{*}{$\begin{array}{l}\text { 10. Have you } \\
\text { received training } \\
\text { on terminal period } \\
\text { patient care? }\end{array}$} & Yes & 29 & $(52.7)$ \\
\hline & No & 26 & $(47.3)$ \\
\hline \multirow{4}{*}{$\begin{array}{l}\text { 13. What is your } \\
\text { attitude towards } \\
\text { the terminal } \\
\text { patient who is } \\
\text { worried? }\end{array}$} & $\begin{array}{l}\text { I ask him to talk to his doctor } \\
\text { or psychologist about such } \\
\text { issues related to his concerns. }\end{array}$ & 32 & $(58.2)$ \\
\hline & $\begin{array}{l}\text { I'll tell him it's nothing, he'll } \\
\text { get better, it's just a process.. }\end{array}$ & 7 & $(12.7)$ \\
\hline & $\begin{array}{l}\text { I'll tell him to accept that he's } \\
\text { going to die anyway, that fear } \\
\text { and anxiety won't help } \\
\text { anymore. }\end{array}$ & 1 & $(1.8)$ \\
\hline & $\begin{array}{l}\text { I have received the necessary } \\
\text { training regarding the } \\
\text { circumstances of death and I } \\
\text { believe I can give the full } \\
\text { support necessary to the } \\
\text { patients and their relatives. }\end{array}$ & 15 & $(27.3)$ \\
\hline \multirow{4}{*}{$\begin{array}{l}\text { 14. What is your } \\
\text { approach to the } \\
\text { treatment of the } \\
\text { terminal patient? }\end{array}$} & $\begin{array}{l}\text { If I think that the treatment } \\
\text { does not help, I think that the } \\
\text { treatment is torture for the } \\
\text { patient. }\end{array}$ & 24 & $(43.6)$ \\
\hline & $\begin{array}{l}\text { I think all treatment should be } \\
\text { continued until the moment of } \\
\text { death }\end{array}$ & 21 & $(38.2)$ \\
\hline & $\begin{array}{l}\text { I think that interventions and } \\
\text { drugs for treatment are } \\
\text { unnecessary and that their } \\
\text { nutrition is enough. }\end{array}$ & 2 & $(3.6)$ \\
\hline & $\begin{array}{l}\text { I think that the patient should } \\
\text { not be forced either in terms } \\
\text { of treatment or nutrition. }\end{array}$ & 8 & $(14.5)$ \\
\hline \multirow{3}{*}{$\begin{array}{l}\text { 15. What } \\
\text { challenges you } \\
\text { most when } \\
\text { treating a terminal } \\
\text { patient? }\end{array}$} & $\begin{array}{l}\text { I think the patient is in pain, } \\
\text { I'm worried about hurting } \\
\text { him/her. }\end{array}$ & 29 & $(52.7)$ \\
\hline & $\begin{array}{l}\text { I'm concerned that the } \\
\text { patient's relatives won't accept } \\
\text { the patient's condition. }\end{array}$ & 12 & $(21.8)$ \\
\hline & $\begin{array}{l}\text { I don't have a hard time in this } \\
\text { proces and I keep my job } \\
\text { routine. }\end{array}$ & 14 & $(25.4)$ \\
\hline \multirow{5}{*}{$\begin{array}{l}\text { 16. How do you } \\
\text { feel when you } \\
\text { witness the death } \\
\text { of your patient? }\end{array}$} & $\begin{array}{l}\text { I take it natural and think it's a } \\
\text { fact of life. }\end{array}$ & 38 & $(69.1)$ \\
\hline & I think his/her pain is over. & 13 & $(23.6)$ \\
\hline & I cry and/or I get very sad & 3 & $(5.5)$ \\
\hline & I get scared & - & \\
\hline & $\begin{array}{l}\text { I'm not emotionally affected, I } \\
\text { do my job. }\end{array}$ & 3 & $(5.5)$ \\
\hline \multirow{3}{*}{$\begin{array}{l}\text { 17. What are your } \\
\text { reasons for } \\
\text { wanting to care for } \\
\text { your terminal } \\
\text { patient? }\end{array}$} & $\begin{array}{l}\text { The dying patient has the } \\
\text { right to receive quality care } \\
\text { and it is the duty of the nurse } \\
\text { to provide care }\end{array}$ & 24 & $(43.6)$ \\
\hline & $\begin{array}{l}\text { Ensuring the patient's } \\
\text { relaxation and peace of mind }\end{array}$ & 25 & $(45.5)$ \\
\hline & $\begin{array}{l}\text { Thinking that death is a } \\
\text { natural process }\end{array}$ & 8 & $(14.5)$ \\
\hline \multirow{2}{*}{$\begin{array}{l}\text { 18. What are your } \\
\text { reasons for not } \\
\text { wanting to care for } \\
\text { your terminal } \\
\text { patient? }\end{array}$} & $\begin{array}{l}\text { Causing a feeling of } \\
\text { helplessness and sadness }\end{array}$ & 16 & $(29.1)$ \\
\hline & $\begin{array}{l}\text { The process is exhausting and } \\
\text { tiring }\end{array}$ & 10 & $(18.2)$ \\
\hline
\end{tabular}

\section{Discussion}

This survey study showed that; although nurses see care as a right, peace and service for the patient in the terminal process, they are reluctant to give care due to pain and inability to change the outcome. Although they are involved in the terminal process, they also avoid communicating with patients and their families. The good death process, which is the natural right of the terminal ill patients, can be realized by the understanding and management of terminal process by the nurses. The increase of anxiety of nurses working with the terminal ill patient, will negatively affect the care they will give. Understanding their feelings about death first will be useful for nurses to manage the process $(1,6)$. Terminal process management is an issue that must be supported by inservice training.

For health professionals, the situation of individuals who have experienced loss and it's important to understand their feelings. Reactions to death significantly affected by their physical, emotional and social experiences $(7,8)$.

Stehle reported that; Holschach defined mental stres in nurses as the inability to recover from the disease, the fear of losing the patient (9).

Our study shows that nurses cannot work in the same unit for a long time due to the fact that they get more tired and wear out spiritually in the special units. In Unsal's study, it was found that as the working year increased, anxiety decreased (10). Although anxiety decreases with experience, we think that working in specialized units for many years causes fatigue and burnout.

In our study approximetly half of nurses do not want to take responsibility, they are reluctant to communicate with patients and their relatives and directing the patient to a doctor. We believe that this rate is insufficient for auxiliary medical staff working in specialized units. Because these units are where terminal process patients receive intensive treatment and care.

"Good death" which can also be defined as receiving treatment to reduce symptoms in patients in the terminal process, reducing invasive procedures, maintaining effective communication with their relatives and being able to say goodbye to the patient's relatives, receiving peaceful and good care in a safe environment, is the fundamental right of every patient (11). In this process, it is extremely important for the nurses, who spend the most time with the patient, to actively participate in the process and to manage the care and process by including the family (12). 
The nurses, $50 \%$ of participating in the survey received training on the terminal process. Although $85 \%$ of them have experienced the death process of any of their relatives, they see "death" as a difficult process. Nurses who do emotional labor in addition to their job responsibilities tend to stay away from the process, patients and their relatives.

Nurses state that they do not know what to say to patients and their relatives during the death process. An article states that the most appropriate approach to death may be to say, "I don't know what to say, but I want to be with you" (13).

Our study showed that the nurses working in the special units of the hospital abstained and had difficulties in managing the terminal process. According to Hurtig WA (14), nurses avoid facing death and communicating with dying patients and their families, despite working with dying patients.

Behaviors expected from nurses such as "continuous communication", "being the person to be reached at all times", "giving patients the feeling that they are safe", "constantly trying to be friendly", "empathizing" and "giving service without expecting anything in return" also cause burnout. In this respect, working continuity is difficult in specialized units. In our study, only $11 \%$ of the participants stated that they had worked in the same unit for more than 2 years.

In order to provide the necessary support to the dying patient and their relatives, it is important for the nurse to know her own feelings about death and to determine her attitudes towards death before completing the education process $(4,15)$. In our study $50 \%$ of nurses participating in the survey received training on the terminal process. We agree with this conclusion that nursing education programs are insufficient to prepare nurses for this process (16).

Managing and caring for the terminal patient requires many skills. Patient care becomes more difficult during this period, which does not benefit from treatment, whose general condition is getting worse, symptoms become difficult to control, difficult questions are asked by patients and their relatives, and emotional and spiritual requirements increase. However, the death of a patient is also a difficult process for the nurse, and it is experienced as a loss. The reactions of the patient and his/her family also make it difficult for nurses. All these difficulties may negatively affect the terminal patient's receiving the care and treatment that he or she deserves (17).

The limitations of our study are that it is singlecentred and only palliative service and intensive care nurses were included as a sample.
We could not create a control group because in our hospital, patients in the terminal process were followed only by intensive care and palliative service nurses, not by wards nurses. Another reason is the low number of participants.

We suggest survey studies to be conducted in larger sample groups before and after the training.

\section{Conclusion}

Although nurses see care as a right, peace and service for the patient in the terminal process, it has been observed that they refrain from giving care due to pain and inability to change the result and avoid communicating with patients and their families.

Therefore, by organizing in-service training, the awareness of the death of nurses for the terminal process, patient communication and emotion management should be increased. It should be aimed both to ensure that the terminal process is manageable for them and to ensure that patients waiting for death get the good death they deserve.

Ethics Committee Approval: Ethics committee approval was received for this study from Research Ethics Committee of University of Health Sciences, Ataturk Chest Diseases and Thoracic Surgery Training and Research Hospital (approval date \& number: 03/05/2020-665).

Peer-review: Externally peer-reviewed.

\section{Author Contributions:}

Concept: G.E.D., Design: G.E.D., Literature search: G.E.D., M.O.C., Data Collection and Processing: G.E.D., M.O.C., Analysis or Interpretation: G.E.D., M.O.C., Writing: G. E. D.

Conflict of Interest: No conflict of interest was declared by the authors.

Financial Disclosure: The authors declared that this study hasn't received no financial support.

\section{References}

1. Cakircali E. Hasta bakımı ve tedavisinde temel ilke ve uygulamalar. 3. Baskı, İzmir: GüvenNobel Tip Kitapevleri, 2000.

2. Akbayrak N. Ölümü yaklaşan hasta ve bakımı. Akdemir $\mathrm{N}$, ed. İç hastalıkları hemşireliği el kitabı. Ankara: Vehbi Koç Vakfı Yayınları, 1998;24-30.

3. Birol L, Fadiloglu C, Akdemir N, Beduk T, Engin $\mathrm{K}$, Esen A ve ark. İç Hastalıkları Hemşireliği El Kitabı. Birlik Ofset. İstanbul, 1998. 
4. Inci F, Oz F. Effects of death education on nurses' death anxiety, depression regarding death, and attitudes towards the dying patient. Anatolian Journal of Psychiatry 2009; 10:253-260.

5. Keskin GU. Cognitive Behavioral Nursing Approach to Dying Patent. Journal of Ege University Nursing High School, 2005. 21(2):125134.

6. Sabuncu N, Alpar SE, Ozdilli K, Batmaz M, Bahcecik N, Ozhan F ve ark. Hemsirelik Bakımında İlke ve Uygulamalar. Ed. Sabuncu N, Alter Yayıncilık, Ankara, 2008.

7. Cavusoglu H. The Importance of Teamwork and Family Care in the Patient with a Terminally Illness. Turk Hemsire Derg. 1984. p:2.

8. Ross Kubler E. Yasamın son günleri, Çev. Editörü: G. Terakye, 2. Basım, Aydoğdu Ofset, Ankara 1995. s:4.

9. Stehle JL. Critical Care Nursing Stres: The Findings Revisited. Nursing Research, 1981. 30(3):182-186.

10.Unsal S. Intensive care unit nurses the idea about death and evaluation of anxiety. Halic University Health Sciences Institute, Istanbul, 2008.

11.Avsar P. Hemşirelik teorileri ve modelleri. Ed: Karadağ A, Çalışkan N, Baykara ZG. 1. Baskı. Akademi Basın ve Yayıncılık; 2017. s.146-164.

12.Burles MC, Peternelj-Taylor CA, Holtslander L. A 'good death' for all? examining issues for palliative care in correctional settings. Mortality, 2016. 21(2):93-111.

13.Trudeu ME. Meeting the challange of a dying patient: Nursing, 1991.91:4247.

14.Hurtig WA, Stewin L. The effect of death education and experience on nursing students, attitude toward death, Journal of Advanced Nursing, 1990. 15(1): 29-34.

15.Bilge A, Embel N, Kaya FG. Attitudes of Students Who will Become Medical Professionals Regarding Death and the Variables that Affect these Attitudes. Journal of Psychiatric Nursing 2013;4(3):119-124.

16. Ay F, Gencturk N. Midwifery Student's Opinions Related to Death, Terminal Period and Palliative Care: Focus Group Study. Florence Nightingale Hemsirelik Dergisi, 2013. 21(3):164-171.

17.Inci F, Oz F. Palliative Care and Death Anxiety. Current Approaches in Psychiatry 2012;4(2):178187 